Review Article

\title{
Study of the Prevalence of Burnout in University Professors in the Period 2005-2020
}

\author{
Iván Fernández-Suárez (D), Maríaluz Arántzazu García-González (D), Fermín Torrano (D), \\ and Guillermo García-González
}

School of Engineering and Technology, Universidad Internacional de La Rioja, Logroño 26006, Spain

Correspondence should be addressed to Fermín Torrano; fermin.torrano@unir.net

Received 14 June 2021; Revised 27 August 2021; Accepted 30 August 2021; Published 11 September 2021

Academic Editor: Ehsan Namaziandost

Copyright (c 2021 Iván Fernández-Suárez et al. This is an open access article distributed under the Creative Commons Attribution License, which permits unrestricted use, distribution, and reproduction in any medium, provided the original work is properly cited.

\begin{abstract}
The purpose of this research is to carry out a systematic review of the existing scientific literature on the prevalence of Burnout in university professors in the time period 2005-2020. For that purpose, an exploratory review through the Web of Science (WoS) and Scopus related to this psychosocial syndrome under the PRISMA methodology has been made. After the application of the inclusion and exclusion criteria, a final group of 12 studies were obtained. The results show the presence of high levels of Burnout in a sample of 2,841 university professors in the period studied, which makes it necessary to implement psychosocial intervention programs to prevent this syndrome and promote the personal and professional accomplishment of teachers.
\end{abstract}

\section{Introduction}

Currently, one of the main focuses of attention for research in the field of work psychology is the mental overload to which workers are exposed [1-4]. In this context, the effective integration of ICT in the workplace has led to the emergence of new work scenarios (such as teleworking or mobile work) and the massive use of electronic devices (tablets and smartphones), aspects that have increased the mental and psychological demands of the tasks faced by workers, causing the appearance of various health conditions, such as musculoskeletal disorders (MSDs), mental fatigue, sleep problems, and Burnout [5-9].

Burnout is a multidimensional syndrome, the prevalence of which, according to different studies, is between $5 \%$ and $45 \%$ of the working population according to the sector and profession of reference, being higher in the health field [10-12]. Specifically, it is usually understood as a psychosocial syndrome, since it is characterized by agglutinating the different symptoms derived from the imbalances between the labor demands and workers' competencies in three fundamental levels: emotional exhaustion, depersonalization, and reduced personal accomplishment. Emotional exhaustion is defined as the lack of emotional resources and the feeling of being exhausted and lacking energy. As for depersonalization, it is identified as the development of negative and insensitive attitudes towards the recipients of the services that are provided. Finally, the reduced personal accomplishment is characterized by negative answers to oneself and one's own work related to episodes of depression, low morale, avoidance of interpersonal-professional relationships, low productivity, inability to withstand pressure, and poor self-esteem [13]. At the same time, research agrees that this syndrome is more common in professionals who work directly with the public, which also entails a progressive loss of motivation, leading towards the development of feelings of inadequacy and personal failure [14-16].

Among the instruments most widely used internationally to assess this syndrome, the Maslach Burnout Inventory (MBI) stands out due to its simplicity in application, its adequate psychometric properties, and the information it provides $[15,16]$. This self-report questionnaire assesses the 
feelings and thoughts of people in their work activity, evaluating the three dimensions indicated above. In the reviewed studies, the General Survey (GS) version has been selected, as it is the most widely used tool at the international level [17], which has allowed the inclusion of a large number of studies and their subsequent comparison.

Education, and especially higher education (University), is one of the areas with the highest prevalence of Burnout [18], which some authors estimate to be $40 \%$ [12]. In this regard, a large number of investigations in recent years have inquired the causes of this fact, attributing it to high psychological demands, low rewards, mental overload, and the high demand to educate people at different stages of their vital development [19-24].

In addition to all of these, the current social-health situation, caused by the advancement of the COVID-19 virus, has generated significant changes at both work and social levels. The main change has been the consolidation of teleworking as a formula to avoid the spread of the virus and avoid social contact $[25,26]$. Although it is still premature to determine what its ultimate impact will be in the workplace, the development of higher levels of stress and exhaustion is expected in all professions, due to the existing uncertainty and the changes that require adapting to this incipient work scenario and the new forms of work related to it.

To the isolation, insecurity, and fear generated by the pandemic, we can add the profound changes that are taking place in education. In particular, there is a change in the teaching model, moving from face-to-face education to a new virtual modality, for which university professors do not have the training, resources, and digital skills necessary to face these challenges [27]. This situation is generating high levels of mental and psychological demands, unplanned digital literacy, and, consequently, a probable increase in the frustration and stress of these workers, which is translating into a higher prevalence of Burnout.

Under this reference framework, the objective of this study is to analyze the prevalence of Burnout in university professors in the last 15 years, in order to make a precise diagnosis of the situation and, in this way, to have an element of comparison from which to analyze in future research the impact that COVID-19 has had on the development of this syndrome in university professors. On the other hand, this systematic review aims to fill a gap in the area of educational research, as most of the studies are focused on primary and secondary education levels. Along with the aforementioned, methodological rigor and relevance are sought, following the guidelines of the PRISMA declaration on the management of this type of study, which guarantees the scientific quality of the findings.

1.1. Review of Literature. Traditionally, research on Burnout syndrome in the field of education has focused on the primary education (6-12 years) and secondary education (12-16 years) stages. However, in recent decades, and as a result of the changes brought about by the phenomenon of social globalization, which has given rise to a new educational reality at this stage [28], concern about this syndrome and its consequences has increased and has extended to the higher education level as well. This new scenario suggests a significant increase in work responsibilities for university professors, with high demands for online teaching, research, publication, and management, and a loss of control due to a lack of resources, a circumstance that substantially favours the development of this syndrome. In addition to these demands, nowadays e-teaching has become a priority as a result of the COVID-19 pandemic, which has added new psychosocial stress factors such as isolation, feelings of technological inefficiency, lack of training, or the difficulty of reconciling personal and professional life [29].

The few existing studies in this field do not provide consistent data on the prevalence of Burnout in the university environment, given the contextual and sample variability contained in such investigations. In this regard, there are some studies such as that by Lackritz [30], in which $20 \%$ of university professors report high levels of Burnout, or more recently, the work carried out by Amir [31], which shows that $40 \%$ of these professors have a high level of this syndrome. Similarly, a systematic review by Watt and Robertson [32] provides similar results. However, there are some studies that differ, such as that by Herranz-Bellido et al. [33], where a very low prevalence of $1.8 \%$ is obtained, and that by Palmer et al. [34], which highlights a prevalence of $2.6 \%$ in a sample of 554 university professors.

Regarding the dimensions that characterize Burnout, it is found that high levels of emotional exhaustion and depersonalization constitute the core of this syndrome [35]. Marenco and Ávila [36], however, identified in a sample of 235 professors belonging to four Colombian university educational institutions that reduced personal accomplishment was the main manifestation of Burnout, whereas depersonalization was the dimension that contributed least to the appearance of this syndrome. Similar results are reported in the study by Ardiç and Polatcı [37].

In line with the aforementioned, there are different factors that have been associated with each of the dimensions of Burnout, some of the personal and, to a large extent, organizational. Emotional exhaustion has been mainly related to gender, with higher scores in women [30, 32, 38, 39]; age, linked to years of experience, which is inversely related to Burnout [28]; use of information and communication technologies (ICT) [7]; and mental overload, mainly as a result of the combination of teaching and management tasks and the pressure to research and publish that university professors face.

In relation to the aspects associated with the depersonalization dimension, there is a lack of emotional support and low optimism [40]. In particular, there is evidence that support from friends and family seems to be a relevant explanatory variable, not only for depersonalization but also for the other two dimensions. Similar results are obtained with self-efficacy beliefs, which are strongly associated with Burnout and its three dimensions.

Finally, the dimension of reduced personal accomplishment has been related to the lack of economic and social rewards [41]. This research shows that in educational 
organizations where there is a balance between effort made and rewards achieved, there is less prevalence of Burnout, sleep disorders, or depression. On the other hand, Kuimova [42] points out that one of the variables related to Burnout is a low salary. Other important factors that have been related to this dimension and to Burnout in general, and which are of great importance nowadays, are the psychosocial risk factors derived from the use of ICT in education, such as isolation, problems in reconciling work and family life, and lack of digital skills [43-45]. On top of this, the COVID-19 pandemic has abruptly led to the abolition of face-to-face lessons (replaced by virtual classes), and teachers have had to struggle against the lack of training, especially during the lockdown, and their feelings of technological incompetence (characterized by a sense of inefficiency and techno-insecurity) [46].

Against this background, one of the aims of the present review is to provide a starting point for a comparative assessment of the situation of postpandemic university professors and examine the extent to which new psychosocial risk factors together with traditionally reported risk factors contribute to the onset and development of Burnout in the university context.

\section{Materials and Methods}

To carry out this systematic review, the guidelines established by the PRISMA statement [27, 47] have been followed, specifically those established in the Preferred Reporting Items for Systematic Reviews and Meta-Analyzes for Protocols version (PRISMA-P 2015) [48]. This protocol includes a 17-item checklist that guarantees the robustness, integrity, and transparency of the research conducted in systematic reviews.

2.1. Source of Information. The first step in the present systematic review was to analyze the main existing scientific databases. To that end, the Web of Science and Scopus were selected as they are the databases with the most relevant impact metrics at the international level nowadays, in addition to having the largest number of publications in their archives.

Web of Science (WoS) is the broadest scientific information platform provided by Clarivate for consulting the databases of the Institute for Scientific Information (ISI). It includes the Science Citation Index Expanded (SCIE), Social Science Citation Index (SCCI), Arts \& Humanities Citation Index (AHCI), and the Emerging Sources Citation Index (ESCI). On the other hand, Scopus is the second international database, in terms of the number of bibliographic references with summaries and citations of the peerreviewed scientific literature, after WoS. It belongs to Elsevier and has tools for monitoring, analysis, and visualization of research.

Once both databases were selected, a search was carried out during the months of June to October 2020, using the terms "Teacher," "Maslach Burnout Inventory," and "University," and alarms were set to notify any publication corresponding to the search completed. The follow-up was carried out until December 2020.

These searches were limited to the period between 2005 and 2020. This period was determined for two reasons: first, to include in this study research that reflects the effect of the integration and intensification of ICT in the workplace and, second, to cut it off in the year 2020, in order to estimate in future research the effect of the COVID-19 pandemic on the increase in the prevalence of Burnout in university professors.

2.2. Data Analysis Techniques. In the first search, a total of 60 articles were obtained in WoS and 84 in Scopus; 21 of them coincided and were added to a total of 123 unique articles. This first block of articles was selected exclusively based on the results provided by the bibliographic searches of both repositories (see Table 1 ):

In a second phase, criteria for exclusion and refinement of the articles were applied according to the PRISMA methodology, in order to be able to homogenize the results of the research. First, the 123 items were analyzed to verify the results that met the criteria set out in Table 1.

For this purpose, the titles, abstracts, and complete documents of the 123 selected articles were read, in order to identify the sample variables (university professors), scientific publication (yes/no), evaluation method used (MBIGS), and how the results are included. These variables were analyzed, identifying 52 articles that included nonconcordant samples, other educational levels, or professional categories or that did not coincide with the position of university professor.

The following verification was based on the inclusion of only scientific articles, discarding 6 documents corresponding to lectures or congressional proceedings not published in article format in a scientific journal. At this point in the process, 58 of the 123 articles initially selected were considered excluded.

With the remaining 65 items, an in-depth analysis was carried out in relation to the research methodology and results. As part of this elimination process, 22 articles that did not apply the MBI-GS and 31 articles that delivered percentage results, Burnout risk levels, or other types of values different from the standard scores of the variables estimated by the instrument were identified. Similarly, those articles that used the tool in a comparative or correlational way without including the direct scores necessary to carry out the analysis process of the present investigation were discarded.

Finally, 12 articles were included in the process of systematic review as can be seen in Table 2 .

\section{Results}

As noted above, after the search process, exclusion, and treatment, a total of 12 scientific articles were included in this systematic review, which are shown in Table 3.

Table 4 lists the 12 studies reviewed with their corresponding objectives and main results obtained. 
TABLE 1: Summary of search criteria.

Inclusion criteria

Information sources

Date of last search

Search strategy

First search results
Period under study: from 2005 to 2020

Language: all

Target population: university professors

Type of documents included: scientific journal articles

WoS and Scopus

December 2020

Search words: "Teacher," "Maslach Burnout Inventory," and "University" 123 items

TABle 2: Exclusion criteria and article refinement.

\begin{tabular}{ll}
\hline Articles analyzed & 123 items \\
\hline Nonconcordant sample & 52 items \\
Articles not published in scientific journals & 55 items \\
Did not apply the MBI-GS & 22 items \\
Results not assimilable to the study & 31 items \\
Articles included in the systematic review & 12 items \\
\hline
\end{tabular}

Table 3: Articles included in the systematic review.

\begin{tabular}{|c|c|c|c|}
\hline$N$ & Publication & Title & Country \\
\hline 1 & Azeem and Nazir [49] & A study of job burnout among university teachers & India \\
\hline 2 & $\begin{array}{l}\text { Flores and Trujillo } \\
{[50]}\end{array}$ & Burnout syndrome and sociodemographic variables in teachers from a private university in Lima & Peru \\
\hline 3 & Padilla et al. [51] & Burnouts syndrome and self-efficacy beliefs in professors & Colombia \\
\hline 4 & Gomes et al. [52] & Cognitive appraisal as a mediator in the relationship between stress and burnout & Portugal \\
\hline 5 & López et al. [53] & Faculty at the University of La Rioja: resilient to burnout? & Spain \\
\hline 6 & Arquero and Donoso & Research, teaching, and burnout: a study in accounting university teaching staff & Spain \\
\hline 7 & Vercambre et al. [55] & $\begin{array}{c}\text { Individual and contextual covariates of burnout: a cross-sectional nationwide study of French } \\
\text { teachers }\end{array}$ & France \\
\hline 8 & $\begin{array}{l}\text { Fabelico and Afalla } \\
{[56]}\end{array}$ & $\begin{array}{c}\text { Perseverance and passion in the teaching profession: teacher's grit, self-efficacy, burnout, and } \\
\text { performance }\end{array}$ & Philippines \\
\hline 9 & Teles et al. [57] & $\begin{array}{l}\text { Perceived stress and indicators of burnout in teachers at Portuguese higher education institutions } \\
\text { (HEI) }\end{array}$ & Portugal \\
\hline 10 & Bedoya et al. [58] & Burnout syndrome in university teachers: the case of a study center in the Colombian Caribbean & Colombia \\
\hline 11 & Gallegos et al. [14] & $\begin{array}{l}\text { Burnout syndrome in school teachers and university professors: a psychometrical and } \\
\text { comparative analysis from Arequipa city }\end{array}$ & Peru \\
\hline 12 & Tijdink et al. [59] & Publication pressure and burnout among Dutch medical professors: a nationwide survey & Holland \\
\hline
\end{tabular}

TABLE 4: List of articles reviewed.

\begin{tabular}{|c|c|c|}
\hline Author & General objective & Results \\
\hline $\begin{array}{l}\text { Azeem and } \\
\text { Nazir [49] }\end{array}$ & $\begin{array}{l}\text { To find out the levels of Burnout among university } \\
\text { professors and to investigate the effects of demographic } \\
\text { variables related to Burnout syndrome }\end{array}$ & $\begin{array}{l}\text { Average levels of Burnout. The main demographic factors } \\
\text { are age and marital status. }\end{array}$ \\
\hline $\begin{array}{l}\text { Flores and } \\
\text { Trujillo [50] }\end{array}$ & $\begin{array}{l}\text { To determine the differences between the components of } \\
\text { Burnout according to demographic variables }\end{array}$ & $\begin{array}{c}\text { Average levels of emotional exhaustion and } \\
\text { depersonalization. Differences are found in emotional } \\
\text { exhaustion depending on gender and work shift and in } \\
\text { personal fulfillment according to years of experience, level } \\
\text { of studies, and age. }\end{array}$ \\
\hline Padilla et al. [51] & $\begin{array}{l}\text { To analyze the relationship between Burnout syndrome } \\
\text { and feelings of self-efficacy with university professors' } \\
\text { academic performance }\end{array}$ & $\begin{array}{l}\text { Low levels of Burnout. Associations between feelings of } \\
\text { self-efficacy and Burnout. }\end{array}$ \\
\hline Gomes et al. [52] & $\begin{array}{l}\text { To analyze the mediating role of the cognitive evaluation in } \\
\text { the relationship between work stress and Burnout }\end{array}$ & $\begin{array}{l}\text { Main sources of stress: work overload, need to increase } \\
\text { productivity in research, and difficulty in reconciling work } \\
\text { and family. The mediating role of the cognitive evaluation } \\
\text { is evident. }\end{array}$ \\
\hline $\begin{array}{l}\text { Jiménez López } \\
\text { et al. [53] }\end{array}$ & $\begin{array}{c}\text { To determine the impact of Burnout on university } \\
\text { professors }\end{array}$ & $\begin{array}{l}\text { 9.4\% of the teachers present moderate or high levels of } \\
\text { Burnout. }\end{array}$ \\
\hline
\end{tabular}


TABLE 4: Continued.

\begin{tabular}{|c|c|c|}
\hline Author & General objective & Results \\
\hline $\begin{array}{l}\text { Arquero and } \\
\text { Donoso [54] }\end{array}$ & To find out the level of Burnout in university professors & $\begin{array}{l}\text { Burnout is higher in professors who mainly work in } \\
\text { research activities. There are significant differences } \\
\text { according to gender, decision-making ability, and not } \\
\text { having a PhD. }\end{array}$ \\
\hline $\begin{array}{l}\text { Vercambre et al. } \\
\text { [55] }\end{array}$ & $\begin{array}{l}\text { To assess the association between personal and contextual } \\
\text { factors and Burnout }\end{array}$ & $\begin{array}{c}\text { Differences according to gender, marital status, and } \\
\text { educational level. }\end{array}$ \\
\hline $\begin{array}{l}\text { Fabelico and } \\
\text { Afalla [56] }\end{array}$ & $\begin{array}{c}\text { To examine the interrelationships between teachers' } \\
\text { characteristics, motivation, self-efficacy, Burnout, and } \\
\text { performance }\end{array}$ & $\begin{array}{l}\text { High values in the depersonalization dimension. No } \\
\text { relationship between self-efficacy and teaching } \\
\text { performance and self-efficacy and Burnout. }\end{array}$ \\
\hline Teles et al. [57] & To assess the impact of Burnout on university professors & $\begin{array}{l}\text { Older (and more experienced) professors have lower levels } \\
\text { of perceived stress. Female professors show higher levels of } \\
\text { emotional exhaustion and perceived stress. The } \\
\text { relationship of perceived stress is directly proportional to } \\
\text { emotional exhaustion and depersonalization and inversely } \\
\text { proportional to self-fulfillment. }\end{array}$ \\
\hline $\begin{array}{l}\text { Bedoya et al. } \\
{[58]}\end{array}$ & $\begin{array}{l}\text { To assess Burnout and factors associated with Burnout in } \\
\text { university professors }\end{array}$ & $\begin{array}{l}\text { High levels of Burnout. Female professors report higher } \\
\text { emotional exhaustion and higher self-fulfillment. Years of } \\
\text { experience are associated with low self-fulfillment. }\end{array}$ \\
\hline $\begin{array}{l}\text { Gallegos et al. } \\
{[14]}\end{array}$ & $\begin{array}{l}\text { To analyze and compare the impact of Burnout on school } \\
\text { teachers and university professors }\end{array}$ & $\begin{array}{l}\text { No significant differences are shown, except for the fact that } \\
\text { university professors score higher on depersonalization } \\
\text { and emotional exhaustion. }\end{array}$ \\
\hline Tijdink et al. [59] & To assess Burnout in professors at the school of medicine & $\begin{array}{l}\text { The level of occurrence is high. Significant associations } \\
\text { between Burnout and perceived level of pressure to be } \\
\text { published. }\end{array}$ \\
\hline
\end{tabular}

For the selection of study data, the results of each article were identified in relation to the use of the MBI-GS. The scale is divided into three subscales, which allow assessing the three dimensions that characterize this syndrome: emotional exhaustion (EE; items 1, 2, 3, 6, 8, 13, 14, 16, and 20), depersonalization ( $D$; items $5,10,11,15$, and 22), and reduced personal accomplishment (PA; items 4, 7, 9, 12, 17, 18,19 , and 21). As a cutoff point (diagnostic criterion), there is no general agreement among researchers to calculate the risk level. The most frequent criterion being the differentiation of three levels of risk considering the upper third diagnosis or confirmation of Burnout (more than 88 points), the middle third tendency to Burnout (between 44 and 87 points), and the lower third without risk of suffering Burnout (from 0 to 43 points).

To carry out the global calculation, a filtering of the samples used in the selected articles was carried out, since some of the studies included multiple samples or their results were broken down by different variables. In addition, some of them took into consideration different variables, such as gender or the type of contract or activity, showing the results in a disaggregated manner. For this reason, in some of the investigations, several samples were taken into account as the information related to the total investigation was not available.

In order to guarantee the homogeneity and veracity of the results, the following adaptations were made:

(i) In the article by Azeem and Nazir [49], three samples of university professors with different job categories (lectures, readers, and professors) are included, the results of which are provided in relation to each category. Therefore, in Table 5, the three samples were analyzed independently (a, b, and c) because the article does not provide a global result.

(ii) In the work of Arquero and Donoso [54], two measurements of the Burnout are made: one in research tasks (a) and another in teaching tasks (b), the results of which were included independently in Table 5.

(iii) The research by Vercambre et al. [55] focuses on teachers of different educational levels, but only the results of the sample of university teachers were taken as a reference. Therefore, data from other educational levels not corresponding to university teaching are discarded.

(iv) In the article by Teles et al. [57], the results are shown by gender; therefore, broadened results were included in Table 5 (women (a) $n=393$ and men (b) $n=181$ ).

Table 5 shows mean scores and their standard deviations as well as the sample size of each item analyzed. In the last row (Total) appears the weighted mean corresponding to the sum of all the studies analyzed in this research, configuring a definitive study, which includes 2,841 university professors in the set of articles included. The global scores of each study and the total mean of the analyzed group are shown.

In the "Burnout" column, the absence of risk is highlighted in green and the suspected risk of suffering Burnout in yellow.

In Figure 1, the position of emotional exhaustion (EE), depersonalization (D), reduced personal accomplishment (PA), and overall Burnout regarding the three identified risk 
TABLE 5: Results of the Burnout variables.

\begin{tabular}{|c|c|c|c|c|c|c|c|c|}
\hline \multirow{2}{*}{ Publication } & \multicolumn{2}{|c|}{$\mathrm{EE}$} & \multicolumn{2}{|c|}{$\mathrm{D}$} & \multicolumn{2}{|c|}{$\mathrm{PA}$} & \multirow{2}{*}{$n$} & \multirow{2}{*}{ Burnout } \\
\hline & M & SD & M & SD & M & SD & & \\
\hline Azeem and Nazir [49] a & 14.05 & 8.53 & 3.99 & 4.12 & 39.48 & 11.49 & 100 & 57.52 \\
\hline Azeem and Nazir [49] b & 9.02 & 9.21 & 5.05 & 5.81 & 36.96 & 9.19 & 100 & 51.03 \\
\hline Azeem and Nazir [49] c & 7.60 & 8.00 & 3.90 & 4.20 & 37.90 & 8.30 & 100 & 49.40 \\
\hline Flores and Trujillo [50] & 12.75 & 5.92 & 1.95 & 2.87 & 15.11 & 2.93 & 260 & 29.81 \\
\hline Padilla et al. [51] & 10.89 & 9.29 & 2.19 & 2.79 & 41.28 & 5.25 & 37 & 54.36 \\
\hline Gomes et al. [52] & 8.62 & 4.78 & 3.11 & 3.37 & 10.90 & 3.92 & 333 & 22.63 \\
\hline Jiménez López et al. [53] & 13.12 & 9.46 & 2.45 & 1.72 & 37.98 & 6.89 & 138 & 53.55 \\
\hline Arquero and Donoso [54] a & 17.50 & 8.40 & 5.20 & 4.20 & 34.20 & 6.90 & 96 & 56.90 \\
\hline Arquero and Donoso [54] b & 24.20 & 10.10 & 5.70 & 4.30 & 27.10 & 8.60 & 96 & 57.00 \\
\hline Vercambre et al. [55] & 18.10 & 10.20 & 3.30 & 3.70 & 31.20 & 8.60 & 161 & 52.60 \\
\hline Fabelico and Afalla [56] & 12.09 & 7.56 & 26.35 & 8.01 & 9.76 & 5.92 & 128 & 48.20 \\
\hline Teles et al. [57] a & 21.49 & 9.31 & 7.07 & 6.96 & 32.69 & 5.60 & 393 & 61.25 \\
\hline Teles et al. [57] b & 19.39 & 9.24 & 8.26 & 7.07 & 33.11 & 0.63 & 181 & 60.76 \\
\hline Bedoya et al. [58] & 17.10 & 10.70 & 6.30 & 5.50 & 40.30 & 5.50 & 150 & 63.70 \\
\hline Gallegos et al. [14] & 15.50 & 8.00 & 7.50 & 6.10 & 29.00 & 10.80 & 131 & 52.00 \\
\hline Tijdink et al. [59] & 11.90 & 7.59 & 4.40 & 4.62 & 30.90 & 5.40 & 437 & 47.20 \\
\hline Total & 14.67 & 8.11 & 5.75 & 4.83 & 28.19 & 5.86 & 2841 & 48.61 \\
\hline
\end{tabular}

Note. The relative mean is shown in relation to the total participating population.

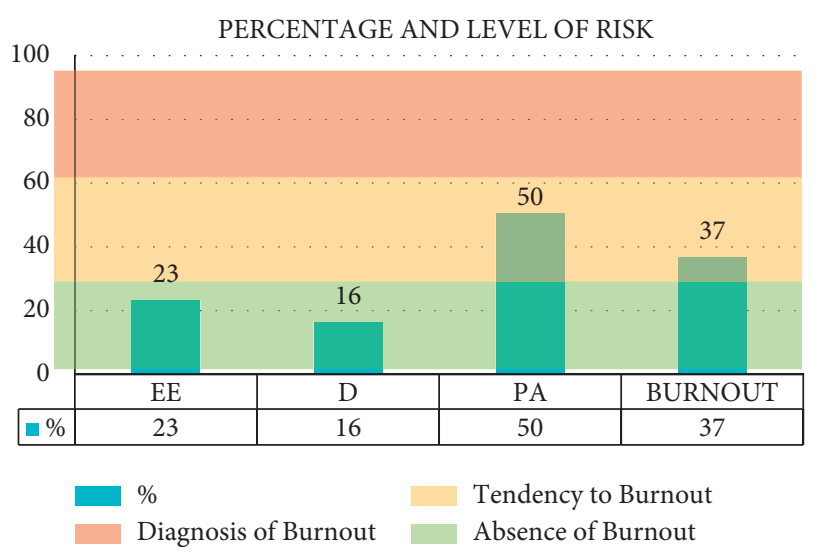

FIGURE 1: Risk levels of the total sample in dimensions EE, D, PA, and Burnout.

levels in each of the corresponding subscales (red: level Burnout diagnostic, yellow: tendency to Burnout, and green: absence of risk) is detailed. As can be seen in Figure 1,37\% of the total sample of university teachers is in a situation of suffering from Burnout.

\section{Discussion}

The results obtained highlight a high occurrence of Burnout syndrome in university professors, as well as a high risk of suffering from it. On the other hand, and in accordance with the multidimensionality of the Burnout construct, certain variability is observed in the scores for the three dimensions that characterize it. These differences are related to the different antecedent and modulating factors operating in each of these dimensions.

Specifically, most of the reviewed studies show a high rate of $37 \%$, a result which is similar to the few studies carried out in the university context $[30-32,60]$. However, two of the reviewed studies $[50,52]$ show a low affectation of Burnout in this environment, in accordance with some studies by Herranz-Bellido et al. [33] and Palmer et al. [34]. The nonconsistency of the data shows the differential value of the different university contexts and samples used in the research $[61,62]$.

Along with the aforementioned, different percentages have been found in the three dimensions, which define this syndrome. To be more specific, the percentage in the emotional exhaustion dimension is $23 \%$; it is $16 \%$ in the depersonalization dimension and $50 \%$ in the low personal fulfillment dimension, which clearly shows a tendency towards Burnout, thereby putting the professors in a position of risk of suffering from it. These findings are coherent with those found by Marenco and Ávila [36], who obtained a high percentage of $42.1 \%$ in the dimension of low professional fulfillment and $23 \%$ and $22.5 \%$ in the dimensions of emotional exhaustion and depersonalization. Similarly, these results are also consistent with the study by Ardıç and Polatci [37], which shows moderate levels of emotional exhaustion and depersonalization and high levels of low personal fulfillment.

The varying degrees of restrictiveness of the criteria used in the research as regards the score that delimits the greater or lower occurrence of Burnout risk explain part of the differences found in the values of each dimension. Furthermore, this divergence emphasizes the relevance of the social context in which Burnout occurs and is more contextrelated than person-related [61].

Regarding the factors related to emotional exhaustion, the work by Teles et al. [57] evaluates the interindividual differences according to gender, providing higher scores for female teachers compared to male teachers. In addition, Arquero and Donoso [54] also find higher mean values of emotional exhaustion in female teachers, and these results are similar to those reported by Watt and Robertson [32], Aimaretti et al. [60], Lackritz [30], Ghorpade et al. [38], and 
Tümkaya [39]. Factors such as social distribution of gender roles and dual presence partially explain this variability.

Another important variable related to this dimension is work overload, which is the main source of stress in the university context [63]. Both these variable and poor control are related to the perception of emotional exhaustion and mental Burnout. Specifically, and in relation to this aspect, the article by Arquero and Donoso [54] indicates that it is especially linked to research activities rather than teaching tasks. At the same time, this factor is related to the obligatory knowledge and mastery of ICT: techno-overload (51).

As for the depersonalization dimension, the results indicate that it is the variable with the lowest level of risk, and these findings are consistent with the studies by Marenco and Ávila [36] and Ardıç and Polatci [37]. However, in Fabelico and Afalla's work [56], a high value is found for this second dimension, although the participants' response is very dispersed or distant from the mean average of the set of data. According to previous research, the enhancement of coping strategies, such as social support, protects against the development of Burnout in general and is related to a lower level of depersonalization [40] as they are incompatible coping behaviours.

Lack of personal fulfillment is the dimension with the highest scores among the reviewed studies, and it is associated with factors such as insufficient rewards received, lack of training and digital skills, and isolation. In this regard, Julieta [41] postulates that personal fulfillment goes beyond the mere and sole financial remuneration and is linked to the prestige or social recognition that provides full meaning to work and constitutes a protective factor for Burnout. Another important factor that has been linked to low personal fulfillment and to Burnout, in general, is the lack of digital skills that can lead to techno-insecurity. In relation to this issue, the obligatory use of ICT in teaching demands that teachers create virtual learning environments beyond their traditional role as transmitters of knowledge, which requires constant updating in light of the rapid development of technological innovations and the mastery of pedagogical and technological content (TPACK) to provide them with quality resources with which to face their new teaching role $[44,45]$. In addition to the foregoing, university teachers must face other risk factors, which are inherent to the use of ICTs, such as isolation, the difficulty of digital disconnection, or the conflict to reconcile family and work [43].

Finally, and in relation to the three dimensions of Burnout, the study by Padilla et al. [51] shows the protective effect of self-efficacy beliefs against Burnout, which is consistent with previous research in this field [40, 64-66].

\section{Conclusions}

In summary, the studies are conclusive regarding the existence of Burnout in university professors. At the same time, it is observed that the worst valued dimension is the personal accomplishment, something significant due to the fact that teaching should be a rewarding task, taking into account its purpose: to help other people achieve their vital and professional goals and to the advancement of society in the proper way. This situation seems to be due, in part, to the demands of university teaching and the expectations that teachers themselves place in their activity. The high demands of the labor market and the responsibility that falls on the university are high. Meeting the expectations of students and the rest of the agents involved (society, companies, public administrations, etc.) significantly increases the pressure on the higher education system. Similarly, mental overload, isolation, lack of training and digital skills, and deterioration in communication, aspects inherent to telework [43], are possible causes that help explain the low scores in the dimension of personal accomplishment. In this sense, it would be interesting to include assessment instruments that delve into the personal accomplishment of teachers (work environment, career plans, reconciliation of work and professional life, etc.), as well as the inclusion of other modulating variables, such as gender and age, in future studies.

The investigations analyzed in this systematic review show the presence of Burnout in university professors. This phenomenon extends globally and has undoubtedly been influenced by the changes produced by the emergence and intensification of ICT in the fields of work and education. The way of educating is changing and the psychological demands to which university teachers are subjected have increased significantly in the last decade. It has gone from a profession of recognized prestige and with a high personal fulfillment to a more impersonal activity, with lower levels of communication and more oriented to the production of degrees than to the generation of scientific knowledge and the improvement of students as people and professionals.

On the other hand, it is observed that the emergence of COVID-19 has caused a substantial change in university teaching, one of its consequences being, to a large extent, the digital transformation. The change from face-to-face teaching to online teaching has occurred without the necessary adaptation processes, so it is expected that its influence on mental load, stress, and therefore, the prevalence of Burnout will be very high in the future.

In order to make an adequate comparison of the possible impact of COVID-19 on the mental health of university professors, it is necessary to know the starting point, the objective of this research. This will allow us to evaluate, in future investigations, the influence of COVID-19 on teachers' occupational health, allowing us to establish strategies that increase the resilience and psychological capital of teachers in the face of this new situation, as well as reduce the negative effects on their health [43, 65]. It is necessary to keep in mind that the starting point can be clearly improved, with high levels of Burnout, which indicates a trend towards its proliferation in the coming years.

As limitation of the study, the difficulty of finding homogeneous samples and results that can be comparable with each other stands out. In the present research, it has been chosen, as it is one of the most widely used assessment instruments at an international level, to use the direct scores of the MBI-GS, but its flexibility and the possibility of presenting the results by scores, risk levels, or percentages make it difficult to compare them. Likewise, it has not been possible to obtain information regarding the way in which 
the questionnaires have been applied. In this sense, it is advisable to establish more standardized procedures for applying the instrument in order to guarantee the confidentiality of the data obtained. This fact is necessary for the participants to be sincere in their responses and obtain more realistic information and greater participation.

Finally, it is considered that the proliferation of teleworking and online teaching, the loss of freedoms, confinement, and isolation, and the fear of the pandemic are aspects that can cause a significant increase in Burnout levels in a demanding profession and with high social responsibility, such as that of a university professor.

\section{Data Availability}

The data used to support the findings of this study are included within the article.

\section{Conflicts of Interest}

The authors declare that there are no conflicts of interest regarding the publication of this paper.

\section{References}

[1] A. Alaimo, A. Esposito, C. Orlando, and A. Simoncini, "Aircraft pilots workload analysis: heart rate variability objective measures and NASA-task load index subjective evaluation," Aerospace, vol. 7, no. 9, p. 137, 2020.

[2] S. S. Bao, J. M. Kapellusch, A. S. Merryweather et al., "Relationships between job organisational factors, biomechanical and psychosocial exposures," Ergonomics, vol. 59, no. 2, pp. 179-194, 2016.

[3] F. S. Then, T. Luck, M. Luppa et al., "Association between mental demands at work and cognitive functioning in the general population-results of the health study of the Leipzig research center for civilization diseases (LIFE)," Journal of Occupational Medicine and Toxicology, vol. 9, no. 1, p. 23, 2014.

[4] J. R. Williamson, K. J. Heaton, and A. Lammert, "Audio, visual, and electrodermal arousal signals as predictors of mental fatigue following sustained cognitive work," in Proceedings of the Annual International Conference of the IEEE Engineering in Medicine and Biology Society, April 2020.

[5] B. Susanne Lehner, J. Jung, B. Stieler-Lorenz et al., "Psychosocial factors in the information and communication technology sector," Management Decision, vol. 51, no. 9, pp. 1878-1892, 2013.

[6] K. Ninaus, S. Diehl, R. Terlutter, K. Chan, and A. Huang, "Benefits and stressors-perceived effects of ICT use on employee health and work stress: an exploratory study from Austria and Hong Kong," International Journal Of Qualitative Studies On Health And Well-Being, vol. 10, no. 1, Article ID 28838, 2015.

[7] M. Soria-Oliver, J. López, F. Torrano, G. García-González, and Á. Lara, "New patterns of information and communication Technologies usage at work and their relationships with visual discomfort and musculoskeletal diseases: results of a crosssectional study of Spanish organizations," International Journal of Environmental Research and Public Health, vol. 16, no. 17 , p. $3166,2019$.

[8] S. Thomée, M. Eklöf, E. Gustafsson, R. Nilsson, and M. Hagberg, "Prevalence of perceived stress, symptoms of depression and sleep disturbances in relation to information and communication technology (ICT) use among young adults-an explorative prospective study," Computers in $\mathrm{Hu}$ man Behavior, vol. 23, no. 3, pp. 1300-1321, 2007.

[9] A. D. Waller and G. Ragsdell, "The impact of e-mail on worklife balance," ASLIB Proceedings, vol. 64, no. 2, pp. 154-177, 2012.

[10] Y. Li, Y. Li, and G. Castaño, "The impact of teaching-research conflict on job burnout among university teachers," International Journal of Conflict Management, vol. 31, no. 1, pp. 76-90, 2019.

[11] L. Ramírez, "Prevalence of Burnout and identification of risk groups in the nursing staff of the Andalusian Health Service," 2019, https://digibug.ugr.es/bitstream/handle/10481/55980/ 68026.pdf? sequence $=4$.

[12] A. Stelmokienè, G. Genevičiūtè-Janonè, and L. Gustainienė, "Job demands-resources and personal resources as risk and safety factors for the professional Burnout among university teachers," Pedagogika, vol. 134, no. 2, pp. 25-44, 2019.

[13] A. Malach-Pines, "The Burnout measure, short version," International Journal of Stress Management, vol. 12, no. 1, pp. 78-88, 2005.

[14] A. Gallegos, J. C. HuamaniCahua, and C. Canaza, "Burnout syndrome in school teachers and university professors: a psychometrical and comparative analysis from Arequipa city," Purposes and Representations, vol. 7, no. 3, pp. 92-113, 2019.

[15] C. Maslach and S. E. Jackson, "The measurement of experienced Burnout," Journal of Organizational Behavior, vol. 2, no. 2, pp. 99-113, 1981.

[16] C. Maslach, W. B. Schaufeli, and M. P. Leiter, "Job burnout," Annual Review of Psychology, vol. 52, no. 1, pp. 397-422, 2001.

[17] J. M. Tomás, S. De Los Santos, A. Alonso-Andres, and I. Fernández, "Validation of the Maslach burnout inventorygeneral survey on a representative sample of Dominican teachers: normative data," Spanish Journal of Psychology, vol. 19, p. E83, 2016.

[18] M. L. García-González, F. Torrano, and G. García-González, "Study of psychosocial risk factors in online university professors: an inside look," Interdisciplinary, vol. 37, no. 1, pp. 1-31, 2020.

[19] M. Acosta-Fernández, L. Parra-Osorio, and C. B. Molina, "Occupational stress, Burnout, mental health and its relationship with workplace violence in university teachers," Salud Uninorte, vol. 35, no. 3, pp. 328-342, 2019.

[20] A. Adil and A. Kamal, "Impact of perceived authentic leadership and psychological capital on Burnout: mediating role of psychological ownership," Psychological Studies, vol. 63, no. 3, pp. 243-252, 2018.

[21] S. Aguilar, P. Howlet, and G. Diez, "Burnout syndrome in teachers of a professional institution in Mexico," Publications Magazine, vol. 45, pp. 53-64, 2015.

[22] I. C. David and S. Quintao, "Burnout in teachers: its relationship with personality, coping strategies and life satisfaction," Acta Medica Portuguesa, vol. 25, no. 3, pp. 145-155, 2012.

[23] J. M. León-Rubio, F. J. Cantero, and J. M. León-Pérez, "Working conditions and differences in the role that selfefficacy plays in the Burnout perceived by University staff," Anales de Psicología, vol. 27, no. 2, pp. 518-526, 2011.

[24] S. Ofei-Dodoo, P. Callaway, and K. Engels, "Prevalence and etiology of Burnout in a community-based graduate medical education system: a mixed-methods study," Family Medicine, vol. 51, no. 9, pp. 766-771, 2019. 
[25] K. Košir, Š. Dugonik, and A. Huskić, "Predictors of perceived teachers' and school counsellors' work stress in the transition period of online education in schools during the COVID-19 pandemic," Educational Studies, vol. 46, no. 5, 2020.

[26] R. Sen, B. Featherstone, A. Gupta, C. Kerr, G. MacIntyre, and A. Quinn-Aziz, "Reflections on social work 2020 under Covid-19 online magazine," Social Work Education, vol. 39, no. 8, pp. 1116-1126, 2020.

[27] A. Liberati, D. G. Altman, and J. Tetzlaff, "The PRISMA statement for reporting systematic reviews and meta-analyzes of studies that evaluate healthcare interventions: explanation and elaboration," BMJ, vol. 339, 2009.

[28] M. L. Avargues and M. Borda, "Job stress and Burnout syndrome at university: a descriptive analysis of the current job situation and review of the principal lines research," Annuary of Clinical and Health Psychology, vol. 6, pp. 67-72, 2010.

[29] C. Rapanta, L. Botturi, P. Goodyear, L. Guàrdia, and M. Koole, "Online university teaching during and after the covid-19 crisis: refocusing teacher presence and learning activity," Postdigital Science and Education, vol. 2, no. 3, pp. 923-945, 2020.

[30] J. R. Lackritz, "Exploring Burnout among university faculty: incidence, performance, and demographic issues," Teaching and Teacher Education, vol. 20, no. 7, pp. 713-729, 2004.

[31] K. Amir, "Prevalence of Burnout among university academic staff in Uganda; Does gender matter?" Clinical Psychiatry, vol. 6 , no. 2 , p. 68,2020 .

[32] J. Watts and N. Robertson, "Burnout in university teaching staff: a systematic literature review," Educational Research, vol. 53, no. 1, pp. 33-50, 2011.

[33] J. Herranz-Bellido, A. Reig-Ferrer, and J. Cabrero-García, "La prevalencia del estrés laboral asistencial entre los profesores universitarios," Análisis y Modificación de Conducta, vol. 32, no. 146, pp. 743-766, 2006.

[34] Y. Palmer, R. Prince, and C. Medina, "Prevalencia del síndrome de Burnout en docentes de la Universidad Autónoma de baja California, Mexicali, México," Revista Cubana de Salud y Trabajo, vol. 17, no. 3, pp. 36-40, 2016.

[35] M. L. Avargues, M. Borda, and A. M. López, "El core of Burnout y los síntomas de estrés en el personal de Universidad. Prevalencia e influencia de variables de carácter sociodemográfico y laboral," Boletin de Psicologia, vol. 99, pp. 89-101, 2010.

[36] A. D. Marenco-Escuderos and J. H. Ávila-Toscano, "Burnout y problemas de salud mental en docentes: diferencias según características demográficas y sociolaborales," Psychologia, vol. 10, no. 1, pp. 91-100, 2016.

[37] K. Ardiç and S. Polatci, "Tükenmişlik sendromu ve akademisyenler üzerinde bir uygulama (GOÜ örneği)," Gazi Üniversitesi İktisadi ve İdari Bilimler Fakültesi Dergisi, vol. 10, no. 2, pp. 69-96, 2008.

[38] J. Ghorpade, J. Lackritz, and G. Singh, "Burnout and personality," Journal of Career Assessment, vol. 15, no. 2, pp. 240-256, 2007.

[39] S. Tümkaya, "Faculty Burnout in relation to work environment and humor as a coping strategy," Educational Sciences: Theory and Practice, vol. 6, no. 3, pp. 911-921, 2006.

[40] J. M. Otero López, M. J. Mariño, and C. Castro Bolaño, “An integrating approach to the study of Burnout in University Professors," Psicothema, vol. 20, pp. 766-772, 2008.

[41] N. Julieta, "Paraiba Valley university teachers occupational stress: burnout, depression and sleep evaluation-Thesis Campinas," Arquivos deneuro-Psiquiatria, vol. 63, p. 367, 2005.
[42] M. V. Kuimova, H. Uzunboylu, and A. S. Chen, "Emotional Burnout in professional activity of a technical university teacher," Ponte, vol. 72, no. 6, pp. 57-61, 2016.

[43] M. A. García-González, F. Torrano, and G. García-González, "Analysis of stress factors for female professors at online universities," International Journal of Environmental Research and Public Health, vol. 17, no. 8, p. 2958, 2020.

[44] H. Özgür, "Relationships between teachers' technostress, technological pedagogical content knowledge (TPACK), school support and demographic variables: a structural equation modeling," Computers in Human Behavior, vol. 112, Article ID 106468, 2020.

[45] K. Schildkamp, I. Wopereis, M. Kat-De Jong, A. Peet, and I. Hoetjes, "Building blocks of instructor professional development for innovative ICT use during a pandemic," Journal of Professional Capital and Community, vol. 5, no. 3/4, pp. 281-293, 2020.

[46] L. Li and X. Wang, "Technostress inhibitors and creators and their impacts on university teachers' work performance in higher education," Cognition, Technology \& Work, vol. 23, no. 2, pp. 315-330, 2020.

[47] D. Moher, A. Liberati, J. Tetzlaff, and D. G. Altman, "Preferred reporting items for systematic reviews and meta-analyses: the PRISMA statement," PLoS Medicine, vol. 6, no. 7, Article ID e1000097, 2009.

[48] D. Moher, L. Shamseer, M. Clarke et al., "Preferred reporting items for systematic review and meta-analysis protocols (PRISMA-P) 2015 statement," Systematic Reviews, vol. 4, no. 1, p. 1, 2015.

[49] S. M. Azeem and N. A. Nazir, "A study of job Burnout among university teachers," Psychology \& Developing Societies, vol. 20, no. 1, pp. 51-64, 2008.

[50] E. A. Rodríguez Flores and M. D. L. Á. Sánchez Trujillo, "Burnout syndrome and socio-demographic variables in teachers from a private university in Lima," Revista de Investigación Educativa, vol. 36, no. 2, pp. 401-419, 2018.

[51] G. Padilla, E. Bonivento, and P. Suarez, "Burnout syndrome and self-efficacy beliefs in professors," Purposes and Representations, vol. 5, no. 2, pp. 65-126, 2017.

[52] A. R. Gomes, S. Faria, and A. M. Gonçalves, "Cognitive appraisal as a mediator in the relationship between stress and Burnout," Work \& Stress, vol. 27, no. 4, pp. 351-367, 2013.

[53] R. A. Jiménez López, A. Pérez de Albéniz Iturriaga, B. LucasMolina, and E. Fonseca-Pedrero, "Faculty at the University of La Rioja: Resilient to Burnout?” Contextos Educativos. Revista de Educación, vol. 24, no. 24, pp. 163-180, 2019.

[54] J. L. Arquero and J. A. Donoso, "Teaching, research and Burnout: the Burnout syndrome in accounting university professors," Revista de Contabilidad, vol. 16, no. 2, pp. 94-105, 2013.

[55] M. N. Vercambre, P. Brosselin, F. Gilbert, E. Nerrière, and V. Kovess-Masféty, "Individual and contextual covariates of Burnout: a cross-sectional nationwide study of French teachers," BMC Public Health, vol. 9, p. 333, 2009.

[56] F. L. Fabelico and B. T. Afalla, "Perseverance and passion in the teaching profession: teachers' grit, self-efficacy, Burnout, and performance," Journal of Critical Reviews, vol. 7, no. 11, pp. 108-119, 2020.

[57] R. Teles, A. Valle, S. Rodríguez, I. Piñeiro, and B. Regueiro, "Perceived stress and indicators of Burnout in teachers at Portuguese higher education institutions (HEI)," International Journal of Environmental Research and Public Health, vol. 17, no. 9, p. 3248, 2020.

[58] E. A. Bedoya, N. E. Vega, C. A. Severiche, and M. J. Meza, "Burnout syndrome in university teachers: The case of a study 
center in the Colombian Caribbean," Formación universitaria, vol. 10, no. 6, pp. 51-58, 2017.

[59] J. K. Tijdink, A. C. M. Vergouwen, and Y. M. Smulders, "Publication pressure and burn out among Dutch medical professors: a nationwide survey," PLoS One, vol. 8, no. 9, Article ID e73381, 2013.

[60] M. P. Aimaretti, M. R. Calizaya, and F. Fernandez, "Promotion of active self-care of university teachers at Universidad Católica de Santiago del Estero-academic Department of San Salvador along 2017," Virtualidad Educacion y Ciencia, vol. 10, no. 19, pp. 88-102, 2019.

[61] C. Maslach, "Job Burnout: New directions in research and intervention," Current Directions in Psychological Science, vol. 12, no. 5, pp. 189-192, 2003.

[62] P. Gil Monte, El síndrome de quemarse por el trabajo (Burnout). Una enfermedad laboral en la sociedad del bienestar, Pirámide, Madrid, Spain, 2015.

[63] N. A. Gillespie, M. Walsh, A. H. Winefield, J. Dua, and C. Stough, "Occupational stress in universities: staff perceptions of the causes, consequences and moderators of stress," Work \& Stress, vol. 15, no. 1, pp. 53-72, 2001.

[64] I. L. Densten, "Re-thinking burnout," Journal of Organizational Behavior, vol. 22, no. 8, pp. 833-847, 2001.

[65] M. Salanova, E. Cifre, and R. M. Grau, "Antecedentes de la autoeficacia en profesores y estudiantes universitarios: un modelo causal," Revista de Psicologia Del Trabajo Y De Las Organizaciones, vol. 21, no. 1-2, pp. 159-176, 2005.

[66] M. Salanova, S. LLorens, and E. Cifre, "Metodología REDWONT. Departamento de Psicología evolutiva, educativa, social y metodología de la Universidad jaume I de Castellón," Perspectivas de Intervención en Riesgos Psicosociales, Evaluación de Riesgos, pp. 131-154, Foment del treball, Barcelona, Spain, 2006. 